\title{
Web-Based Neighborhood Management Information System Using Laravel PHP Framework (Case Study RT. 07 Manggung, Wukirsari, Imogiri, Bantul)
}

\author{
Johan Setiawan ${ }^{1 *}$, Arif Rahman ${ }^{2}$, Bambang Sugiantoro ${ }^{1}$ \\ ${ }^{1}$ Informatics Department, Faculty of Sains and Technology UIN Sunan Kalijaga, Indonesia \\ ${ }^{2}$ Information System Department Faculty of Sains and Technology Universitas Ahmad Dahlan Yogyakarta, Indonesia \\ Email*: johan.react@gmail.com
}

\begin{abstract}
Management and management of data is one of the most important things for neighbor administrators, so data and information related to the notulency, attendance, financial and assets must be accessed quickly and precisely. RT 07 Hamlet Manggung is the government line that is closest to the Community. Currently the recording of data for Notulency, attendance, family cards and assets is still Manual and has not used any technology that improves effectiveness in data management pillars Neighbors. This system is built using Unified Software Development development method process (USDP), with the Unified Modelling Language (UML) modelling. In the inception phase all RT management data related to system requirements, elaboration phase is done to expand management system concept that already formed in phase inception, phase contruction done making management system, and in the transition phase is done to expand the system. Management. This maturation needs to be done to analyse whether the information system that has been made according to user needs. Then the system is built with the language PHP programming and MySQL databases using the Laravel framework, once it is done test system using alpha test and beta test.
\end{abstract}

Keywords: Database, laravel, role, USDP, UML

\section{INTRODUCTION}

The closest community organization to the real community in governance is the RT level where the agency interacts or provides services directly with the community that has been determined by the village or kelurahan government. RT 07 which is located in the areas of Manggung, Wukirsari, Imogiri, Bantul has several areas separated by rice fields and several agencies, therefore in one RT they are separated into three areas. Thus the relationship between neighbors becomes very far away. Therefore, in providing services to the community RT managers often get into trouble. Starting from the head of the RT who cannot know the data analysis quickly and accurately. The RT secretary takes too long to make an invitation to the event and an introductory certificate used to take care of KTP, Family Card and birth or death certificates. The treasurer takes too long to calculate the monthly financial statements. Asset managers are less careful in recording loans and repayments so that errors often occur in recording the amount of assets available. And residents who want to know RT minutes and financial data.

In accordance with Law Number 24 of 2013 concerning Amendment to Law Number 23 of 2006 concerning Population Administration which was ratified by the Indonesian Parliament on November 26, 2013 which is a fundamental change in the population administration field. The main purpose of the amendment to the law in question is to increase the effectiveness of population administration services to the community, guaranteeing the accuracy of population data and the unity of Population Identification Number (NIK) as well as the unity of population documents.

In accordance with the Law above, the hope for the development of an RT (SIM-ERT) management information system within the RT is that RT administrators will be easier to manage RT data, making it easier for residents to see the results of deliberations recorded by the secretary in the SIM- ERT, accelerates the making of a citizen introduction certificate, facilitates the management of RT assets and accelerates the analysis of community data so that it is faster in making decisions and achieving the objectives of RT managers.

\section{MATERIALS AND METHODS}

\section{Study area}

The research subject that will be discussed is the creation of a management information system for the neighborhood association case study RT.07 Manggung, Wukirsari, Imogiri, Bantul, Yogyakarta using the Laravel framework. With this research, it is expected to provide a tetanga pillar management information system which can make it easier for RT managers to manage minutes, assets and financial data. And the public can see general data that is managed by the RT administrator. 


\section{Procedures}

\section{- Observation method}

Observation method was carried out to find out how the process of managing assets, events and finances manually carried out by RT managers, see first hand the transaction process in the stages of asset lending, observe the process of recording minutes and data collection at each event.

\section{- Interview method}

Interviews method were carried out directly to the Head of RT and community leaders who knew the workflow of the system so as to get real data and in accordance with the desired conditions.

\section{- Literature study}

Literature study is a method of collecting data which is done by searching, reading and collecting documents as a reference. Reference sources used are books, articles and literature - final project related to the topic raised regarding the Neighborhood Information System Management or population.

\section{- Documentation method}

Documentation method is used to find population data, event data, asset data and financial data. These data are used to analyze the data requirements of the system to be built.

\section{Data analysis}

\section{- USDP (Unified Software Development Process)}

According to Bennet, et al (2006). USDP method or also called denagn UP (Unified Process) is one method of software development, primarily object-oriented software. This methodology was first introduced by the Rational Team. USDP is used to build frameworks that can be customized for specific organizational or project interests. With the framework can be created various applications because of the concept of coding, reuse, where the same coding can be used for similar systems. Each phase illustrates the emphasis on activities that are important in system development. These phases are described in the form of workflows which consist of a series of activities. The Phases in USDP are as follows:

a. Inception

In this phase, software developers interact with customers, as a first step to identify the system requirements to be made. This step is quite important so that software developers have the same perception between the system that will be made with user needs.

b. Elaboration

This phase is used to mature concepts that have been formed in the inception phase. This phase has not entered the stage of making software directly, but rather the strengthening of concepts and a review of predetermined plans. Thus the risk can be reduced to a minimum.

\section{c. Construction}

This phase is the coding phase, where the software developer has made a real system development. Making the system certainly refers to things or parameters that have been determined and outlined from the previous phase.

\section{d. Transition}

This stage is carried out to finalize the finished product. This maturation needs to be done to analyze whether the software has been made according to user needs, or there may be bugs that need to be fixed, and others.

The following is an overview of the system development workflow using the USDP method:

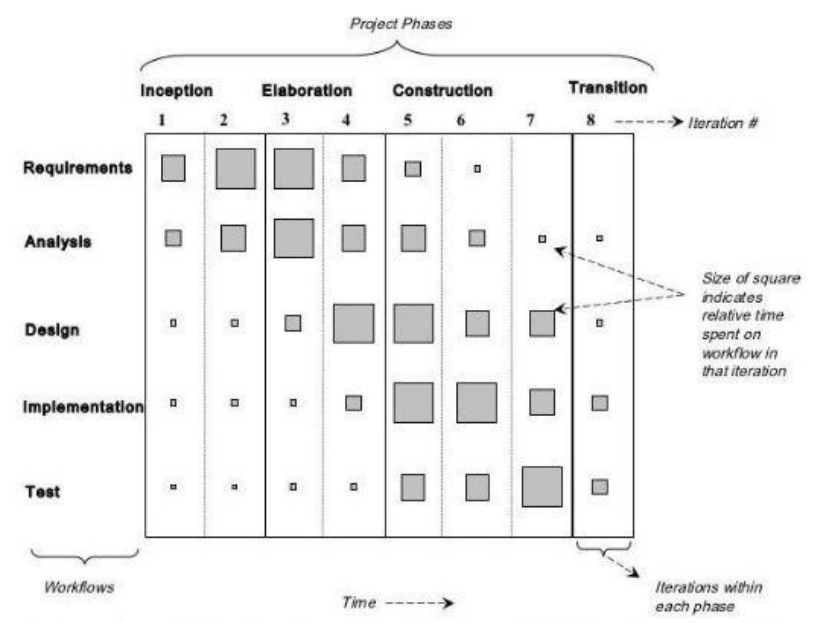

Figure 1. Unified Software Development Process. Source: Bennet et al., 2006.

\section{- UML (Unified Modeling Language)}

Unified modeling language is the standard language for writing software designs. UML can be used to build and document software frameworks. On the other hand, by building architectural designs for use by construction companies, software builders create UML diagrams to help software developers to build software. So it is easier to understand, easy to determine the system and easy to explain the system design (Pressman, 2010).

a. Use Case Diagrams

Used to help determine software functions and features from a user's perspective. Use cases explain how users interact with the system by defining the steps needed to achieve certain goals. Use case diagrams are an overview of all use cases and the relationship between each use case. In the use case diagram, the use case is displayed in an oval shape. The actors are connected with each use case using lines. Because the use case diagram displays all the use cases, it is very helpful to ensure that all functions of the system are included (Pressman, 2010). 
b. Activity Diagram

Activity diagram explains the dynamic behavior of the system or parts of the system through the process flow by the system. This is the same as the flow chart model but is slightly different because the activity diagram can display the system process flow simultaneously. The main component of the activity diagram is the action node, represented by a rounded rectangle, which corresponds to the task performed by the arrow software from one node to another describing the flow of control. This means that after the first action is finished, the second action is only executed. A deep black circle describes the beginning of the activity process. A black dot surrounded by a black circle describes the end of the activity process. Black horizontal line separates two or more actions simultaneously. (Pressman, 2010).

c. Class Diagram

The main element in a class diagram is a box, which is an icon used to represent a class. Each box is divided by a horizontal line. The top part contains the name of the class. The middle section contains the attributes of each class. Each attribute refers to something that is an object in the class. Each attribute can have a name, type and symbol. Symbols are indicated by -, \#, or +, each of which indicates that the attribute is private, protected, package or public. (Pressman, 2010).

\section{RESULTS AND DISCUSSION}

\section{Requirements and Capture Modeling}

The process of analyzing and designing an application using USDP starts with defining / determining requirements. The requirements for functional and nonfunctional devices are as follows.

a. Functional requirements

b. Non-functional requirements

Non-functional needs in operations that must be met by the neighborhood association management information system has the following specifications:

- The system can be operated on desktop PCs, notebooks, tablets

- The system must be able to work on a web browser

- The system must be multiplatform accessible

Requirements are described using a use case diagram. Use case diagrams will serve as guidelines for the next step in the analysis and design. There are six users who are described using the use case diagram, namely administrator, RT chief, secretary, treasurer, asset manager, personal.
Table 1. Functional Requirements.

\begin{tabular}{ll}
\hline Functional Req & Description \\
\hline Family Card Data & $\begin{array}{l}\text { The system can help users to archive } \\
\text { family card data, the system can } \\
\text { display family card data and its } \\
\text { members, the system can help print } \\
\text { family data. } \\
\text { The system can help users to manage } \\
\text { events on the Neighborhood } \\
\text { Association, the system can make } \\
\text { automatic invitations based on criteria, } \\
\text { the system can help users to manage } \\
\text { attendance data at the event, the system } \\
\text { can assist in recording the minutes of } \\
\text { events. } \\
\text { The system can help users to make } \\
\text { asset lending transactions, the system } \\
\text { can display assets available for } \\
\text { borrowing, the system can make asset } \\
\text { loan reports. } \\
\text { The system can help to record the entry } \\
\text { and exit of financial data in the } \\
\text { financial ledger, users can make } \\
\text { financial statement data according to } \\
\text { the date specified on the system, the } \\
\text { system can assist in printing financial } \\
\text { statement data. }\end{array}$ \\
\end{tabular}

\section{Requirements Analysis}

The next activity is conducting requrements analysis. Analysis of user requirements for the system will be used with use case diagrams. Use cases that can represent all user roles, which is administrator. The following are the results of the analysis of the role.

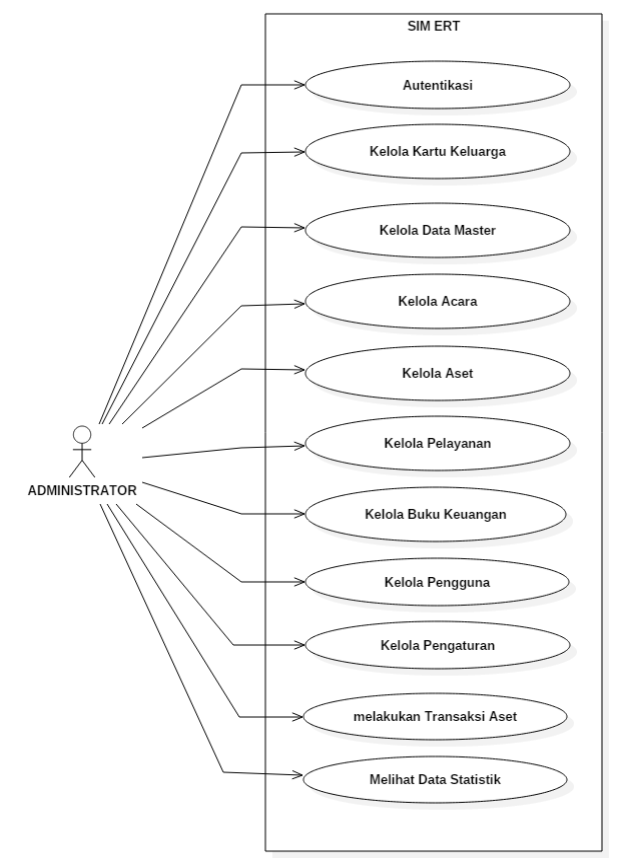

Figure 2. Administrator use case diagram. 


\section{System design}

In system design activities, the basic activities of the user are identified using the activity diagram.

\section{- Login Activity Diagram}

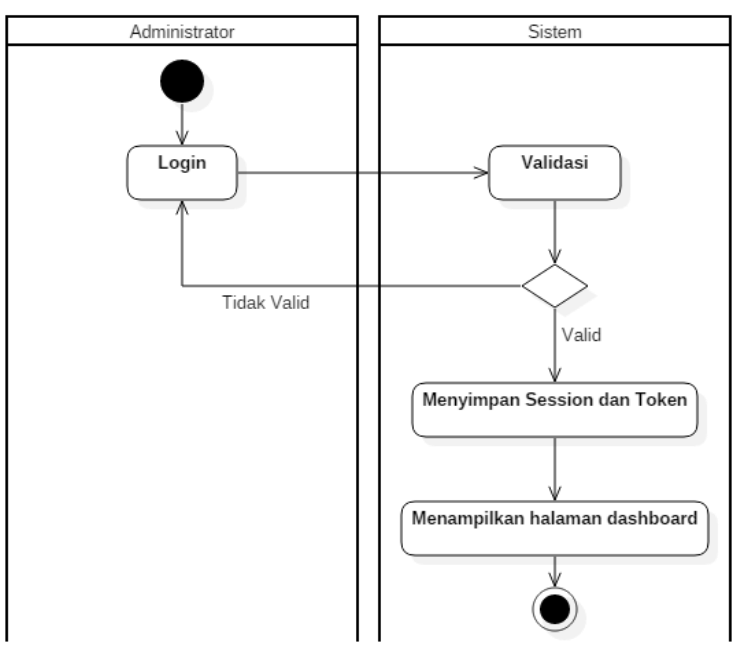

Figure 3. Login activity diagram.

The Figure 3 is describing the user activities entering the main page (dashboard). The user must log in first, by entering the NIK and password. If the NIK and password are invalid then the user must return to the login page, and if valid then the user will enter the main page (dashboard).

\section{- Add User Activity Diagram}

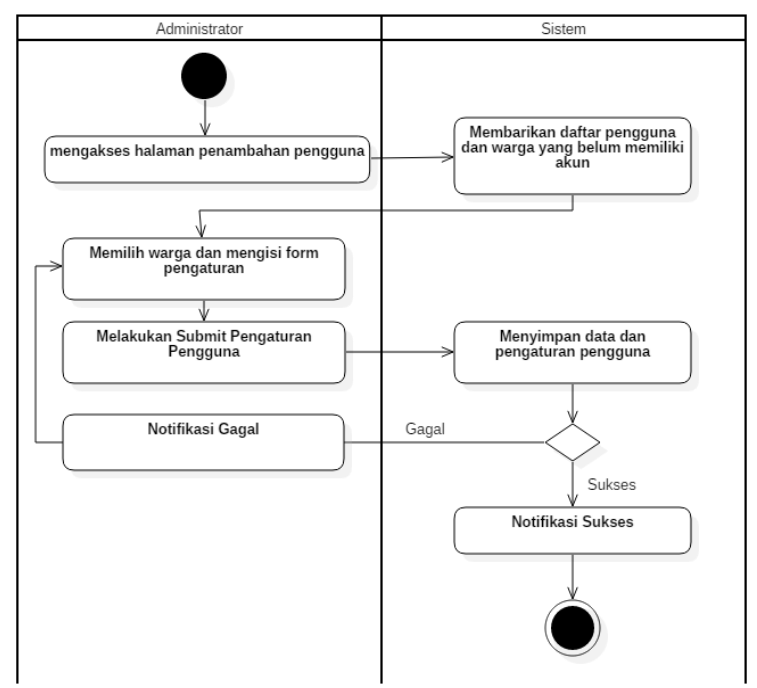

Figure 4. Add User activity diagram.

Figure 4. is describing the activities of administrators adding users from the data citizens who are not yet users, the administrator chooses citizens to be users by setting roles and passwords, if set, the administrator submits. If the user is successfully created, the system will give notification of success, if it fails the system will give notification of failure.

\section{- Add Family Card Activity Diagram}

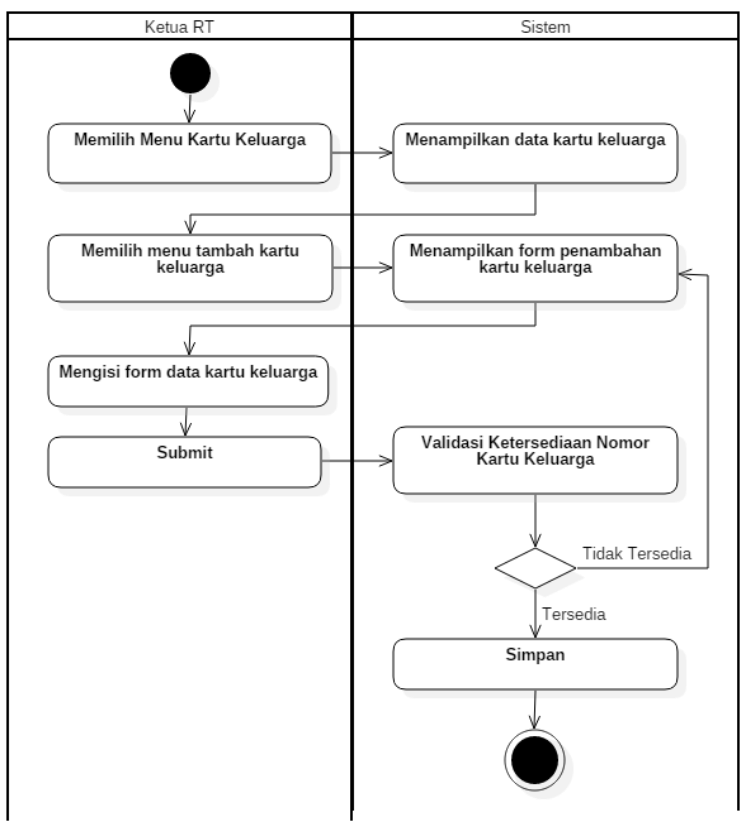

Figure 5. Add Family Card activity diagram.

Figure 5 describe the activities of the RT Head adding family card data. The RT Chairperson adds family card data from the form provided by the system with validation of the availability of family card numbers, if no other family card numbers are used within the RT, then new family card data can be stored.

\section{- Add Event Card Activity Diagram}

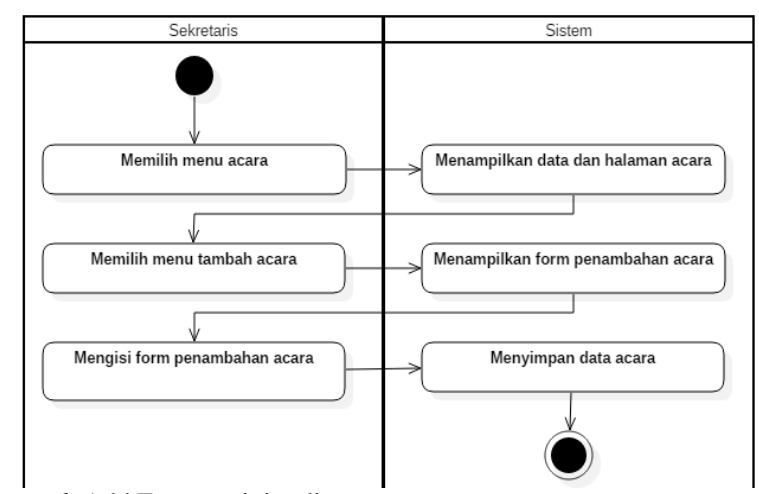

Figure 6. Add Event activity diagram.

Figure 6 describe the activities of the secretary in the process of making events on the system. The secretary makes the event through a form provided by the system then the system receives the event and is stored in a database. 
- Add Financial Report Activity Diagram

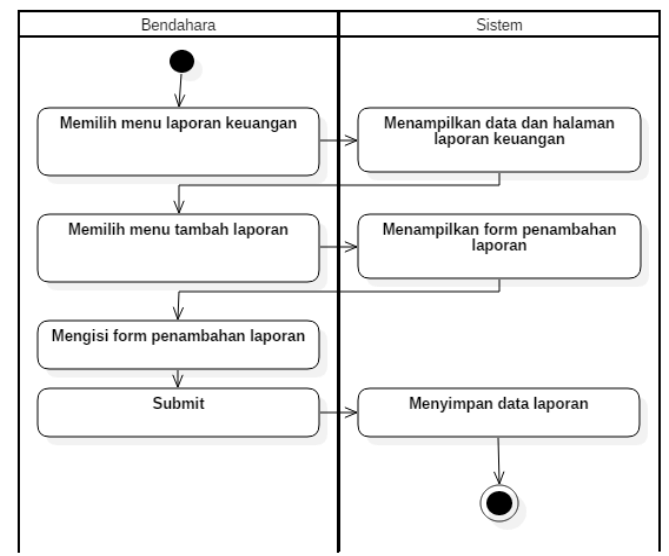

Figure 7. Add Financial Report activity diagram.

Figure 7 describe the activities of the treasurer in adding data to the financial statements. In the process of adding financial statements the system provides a form that contains the date range that will be made the report.

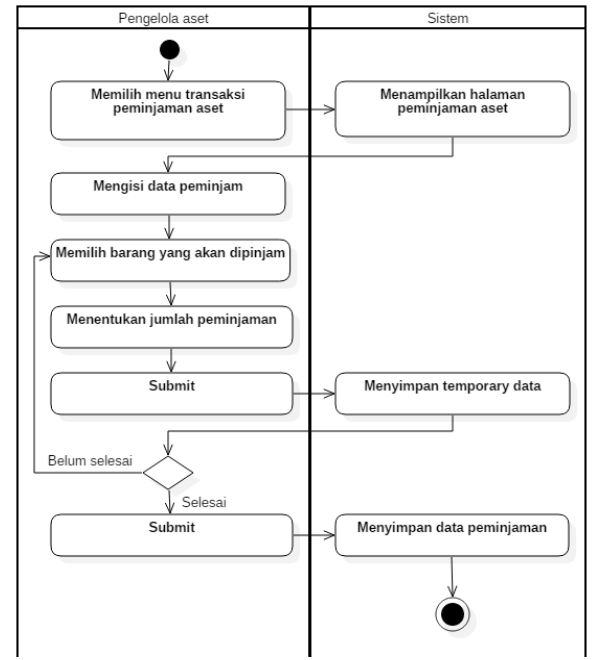

Figure 8. Add Borrowing Transaction activity diagram.

Figure 8 describe the activities of asset managers in conducting transactions/borrowing assets. Assets that can be borrowed are only those assets that are still available or not borrowed.

\section{- Add Borowing Assets Activity Diagram}

\section{Class Design}

Figure 9. Class Design

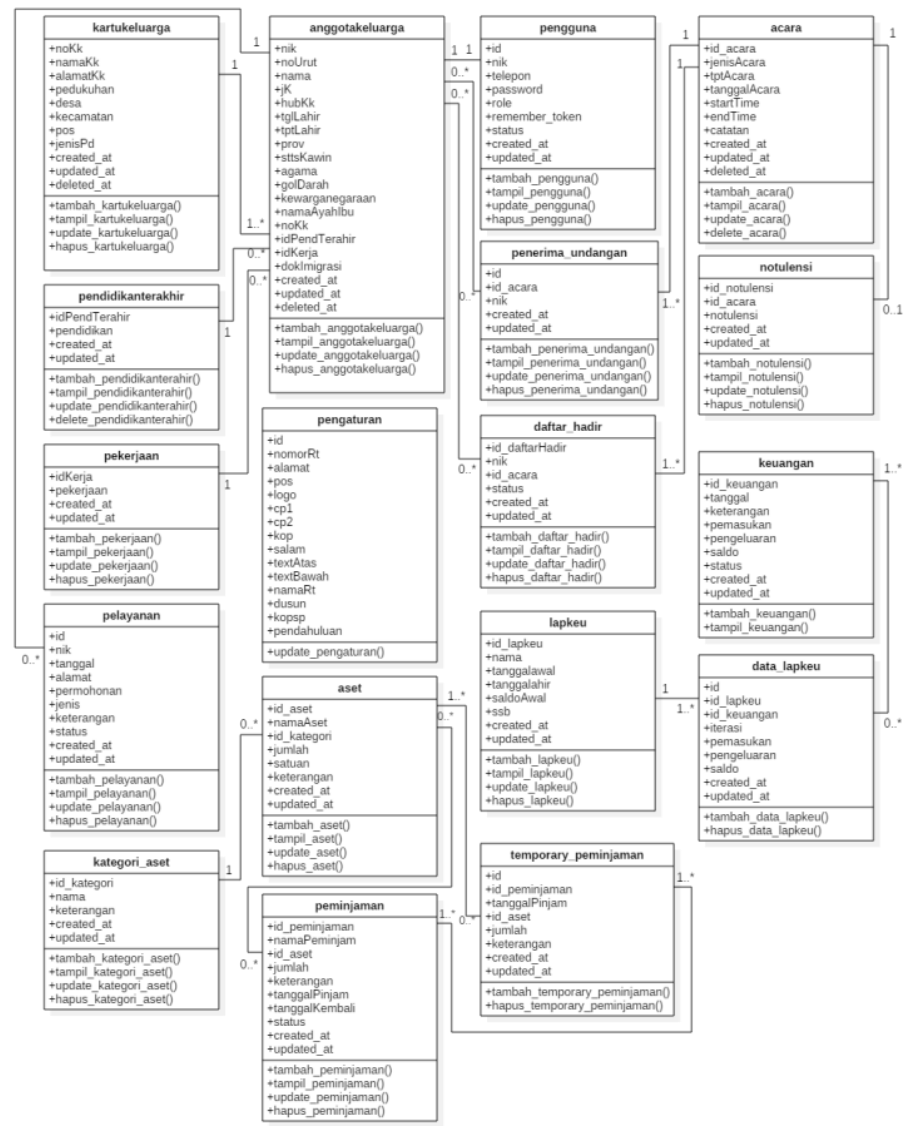

\section{Data Management Design}

Based on the design class, a database for the management information system of the neighboring neighborhood is given the name sipenduk_db with relations between the tables which can be seen in Figure 10 : 


$$
\begin{array}{ll}
* & =\text { Primary Key } \\
* * & =\text { Foreign Key }
\end{array}
$$

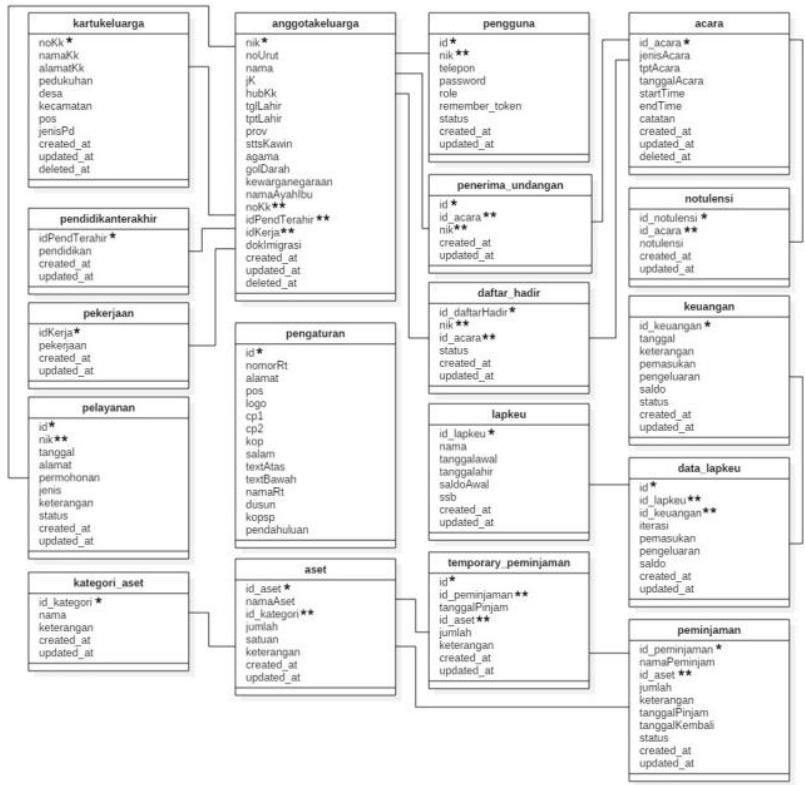

Figure 10. Data Management Design.

\section{User Interface Design}

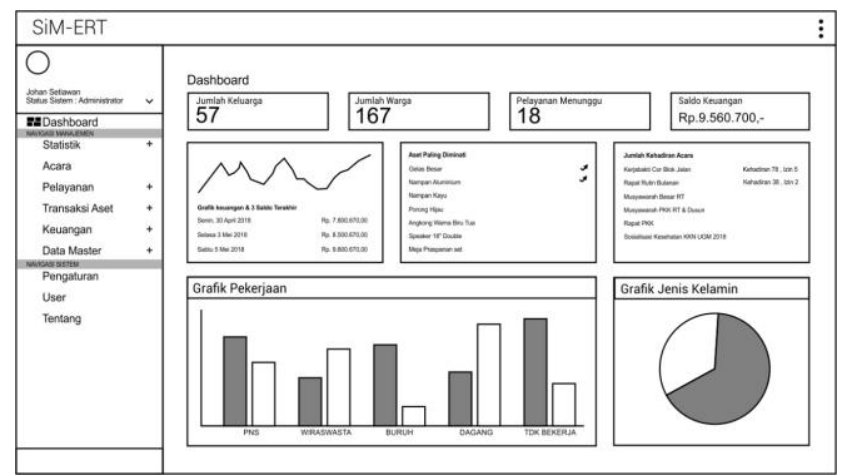

Figure 11. Dashboard User Interface Design.

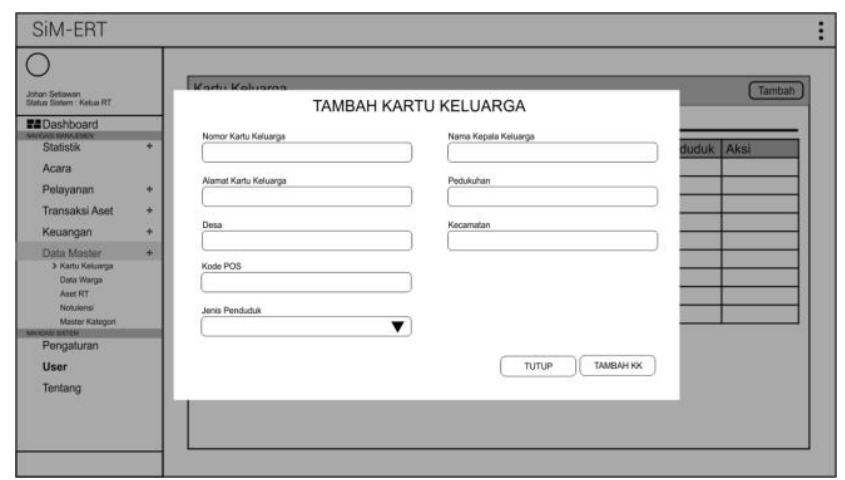

Figure 12. Add Family Card User Interface Design.

\section{Construction}

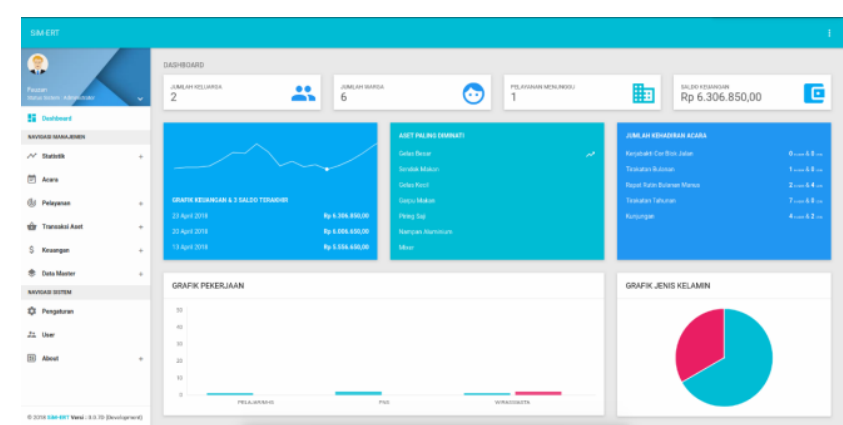

Figure 13. Real Dashboard.

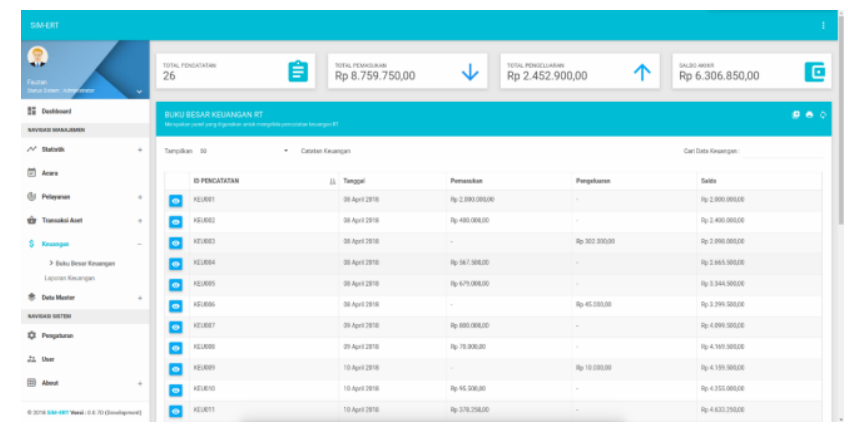

Figure 14. Financial Report Dashboard.

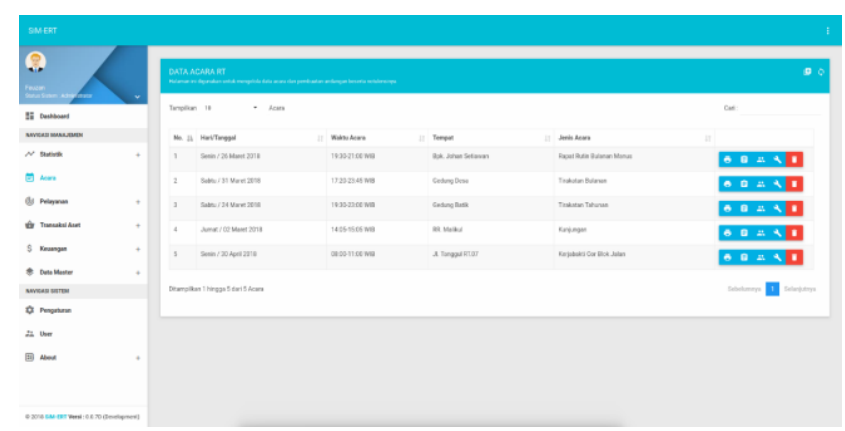

Figure 15. Event Module.

\section{CONCLUSIONS}

Based on the results of research conducted when making a Neighborhood Information Management System can be concluded as follows:

1. The neighborhood management information system built in RT 07 Manggung, Wukirsari, Imogiri, Bantul can be used by RT managers to manage citizen data and activities in accordance with user roles that have been determined in the RT area.

2. The system built can display community data analysis based on the data that has been stored. SIMERT can display job analysis data, blood type, age, recent education and gender in graphical form. 


\section{ACKNOWLEDGEMENTS}

This research was supported/partially supported by ICSE. We thank our colleagues from Ahmad Dahlan University and Islamic State University of Sunan Kalijaga who provided insight and expertise that greatly assisted the research, although they may not agree with all of the interpretations/conclusions of this paper.

\section{REFERENCES}

Aminudin. 2015. Cara Efektif Belajar Framework LARAVEL. Lokomedia, Yogyakarta

Bennet S, Steve M, Ray F. 2006. Object Oriented Systems Analysis and Design Using UML. McGraw Hill, UK.

Mulyanto A. 2009. Sistem Informasi Konsep dan Aplikasi. Pustaka Pelajar, Yogyakarta.

Pressman RS. 2010. Pendekatan Praktisi Rekayasa Perangkat Lunak: Edisi 7. Penerbit Andi, Yogyakarta. 
THIS PAGE INTENTIONALLY LEFT BLANK 